\title{
Messiás: A Red Wine Cultivar
}

\author{
Péter Szabó, Barnabás Kovács, and László Kocsis \\ University of Pannonia, Georgikon Faculty, Department of Horticulture, \\ Keszthely 8360. Hungary
}

Additional index words. breeding, red wine, Vitis vinifera

In 1803, an internationally significant grapevine collection was established at the Georgikon Faculty (an institute of independent higher education in the field of agronomy), Hungary, aiming to introduce new cultivars into practice.

In the framework of the national grapevine breeding program, clonal selection was started with the selection of 'Olaszrizling' in 1949. (Syn.: Italian riesling, Welschriesling, Laski Rizling). Later on, the classical cross-breeding was processed in the 1950s. There are six cultivars (Cserszegi füszeres, Nektár, Korona, Pátria, Rozália, Pelso) in the Hungarian National Catalogue of Cultivars (https://portal.nebih. gov.hu/) as a result of these breeding efforts.

Messiás is a result of crossing Dunaj and Merlot grape cultivars (Fig. 1). The aim was to create an early ripening grape cultivar with tolerance to abiotic factors (e.g., intemperate weather) combined with the benefits of established cultivars and with new features that meet today's expectations. Preserving its fruity nature, it is possible to make an easyto-consume wine with good acids. The goal was to complete harvesting and processing before traditional cultivars. In addition, drought tolerance, yield, wine quality, easy propagation, and introgression of maximum disease resistance were also important.

A new red wine grape cultivar of the University of Pannonia Georgikon Faculty has been presented, based on our own cultivar experiments and those of the National Food Chain Safety Office (NFCSO).

\section{Origin}

Cross-breeding was planned in a larger context of red wine breeding program in the late 1990s. The mother plant 'Dunaj' was chosen because of its early ripening time and color and because its cluster architecture is semitight [according to Office International de la Vigne et du Vin (OIV) descriptors], inherited from its ancestors. The second parent, 'Merlot', has favorable characteristics and

Received for publication 26 July 2019. Accepted for publication 30 Sept. 2019.

Published online 7 January 2020.

We acknowledge the financial support of Széchenyi 2020 under the EFOP-3.6.1-16-2016-00015.

P.S. is the corresponding author. E-mail: szabopeter@ georgikon.hu.

This is an open access article distributed under the CC BY-NC-ND license (http://creativecommons.org/ licenses/by-nc-nd/4.0/). relatively short vegetative cycle, fruity aromas in its berries and in the wines (Table 1).

This red wine cultivar was granted state recognition of Hungary at the University of Pannonia Georgikon Faculty in 2018. On the basis of our experiments and the cultivar analysis by NFCSO, 'Messiás' is the latest red wine grape cultivar cultivated at the university. We compared the results of cultivar evaluations in four locations (Domoszló, Helvécia, Pölöske, Cserszegtomaj) and various vintages of the red wine grape cultivars grown in Hungary (Kékfrankos, Merlot, Cabernet Sauvignon). We collected the following data: crop yield, ripening and harvest time, grape nutritional value and wine chemistry (titratable acidity, tartaric acid content, sugar-free extract, Brix), frost tolerance, average cluster and berry weight, average points of sensory tests, and degree of botrytis incidence.

\section{Statistical Methodology}

To compare the characteristics of the cultivars of grapes and wines, the one-way analysis was applied. If any data violated the assumption of homogeneity of variances, the Brown-Forsythe test was used. In the last column of Table 1 where the $P$ value is indicated, it indicates the homogeneity of variance test is shown in brackets. If the difference between cultivars was significant on the basis of analysis of variance test results, we applied the Scheffe post hoc test.

In the Domoszló and Helvécia location cluster weight, the greater scattering of the 'Kékfrankos' and the 'Messiás' prevented demonstration of a significant difference. In the case of Pölöske, with a small scattering, the weight of the cluster is significantly lower than that of the other two cultivars of the Messiás.

The normal distribution of berry weight was not justifiable (Domoszló and Pölöske). Instead of the parametric test, we used the nonparametric Kruskal-Wallis test for the examination of the difference in berry weights by cultivar. With this method, a significant difference could be justified in the case of 'Domoszló' $(P$ value of Kruskal Wallis $=0.022$, pMedian $=0.012$ ). In the case of 'Pölöske', Kruskal Wallis did not, but the median test indicated a significant difference $($ Kruskal Wallis $=0.054$, Median $=0.043)$.

\section{Description and Performance}

The cultivar was examined in four locations: vines planted in umbrella training system in the Domoszló area in spring 2011, the cordon of medium height plantation in Helvécia planted in 2011, the cordon of medium height plantation of 2010 in Pölöske, and the experimental site of University of Pannonia in Cserszegtomaj (Fig. 2). Vine and row spacing was $3 \times 1 \mathrm{~m}$ on each of the experimental vineyard sites.

Cluster characteristics. The cultivar displays good fruit set with 90 to 100 berries per cluster (Fig. 3). Its fertility is appropriate, and it is not susceptible to uneven ripening. The cluster is medium-sized, length of the peduncle is short (according to OIV 206), the 4-year average weight of the cluster in Domoszló was $131 \mathrm{~g}$ and in Helvécia was $155 \mathrm{~g}$. The berries are small, and the average weight of the berry was $1.4 \mathrm{~g}$ in both production sites according to OIV descriptors (OIV 503). In Pölöske, the average cluster weight was 149 $\mathrm{g}$, and berry weight was $1.8 \mathrm{~g}$. Its blue-black berry is round, soft, and juicy. The berry skin is thick, and cracking was not observed. Its taste is neutral, or a slight herbal flavor can be noted.

Ripening. The cultivar achieved $>20^{\circ}$ Brix at harvest (Table 1). In Helvécia, it was harvested at a higher Brix compared with Kékfrankos and Merlot. In Domoszló, the Brix measurements were similar to Kékfrankos. Grape producers observed that in most vintages, Messiás is harvested at 21 to $22^{\circ}$ Brix in the first half of September (Table 1). The Brix of grapes at the Pölöske site was lower relative to the other sites. This was likely because the site was the coldest experimental site and had compacted clay soils.

Productivity. The productivity of the cultivar is shown in Table 1. According to the data, the fertility of the cultivar in Helvécia and Domoszló was good-moderate but did not reach the productivity of 'Kékfrankos' or 'Merlot'. The analyses of the university showed similar results but the yields were less than 'Merlot'. The comparative frost tolerance of 'Messiás' is good, similar to the Kékfrankos cultivar. Its buds tolerate cold weather better than those of 'Merlot'.

Wine characteristics. The titratable acid content of its must was between 6.3 and $7.8 \mathrm{~g} / \mathrm{L}$, lower than those of Kékfrankos and Merlot cultivars according to Balga (2014). The sugar-free extract content was high, 2 to $3 \mathrm{~g} / \mathrm{L}$ higher than in case of the comparative

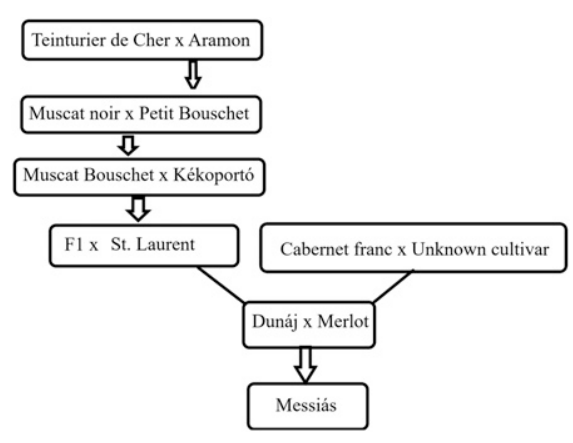

Fig. 1. The pedigree of the new cultivar Messiás. 
Table 1. Cultural characteristics of Messiás compared with Merlot and Kékfrankos cultivars.

\begin{tabular}{|c|c|c|c|c|}
\hline & Kékfrankos & Merlot & Messiás & $P=0.05$ \\
\hline \multicolumn{5}{|c|}{ Average weight of the cluster (grams) } \\
\hline Domoszló & 191 & 160 & 131 & $0.055(0.006)$ \\
\hline Helvécia & 183 & 178 & 155 & $0.068(0.296)$ \\
\hline Pölöske & $187 \mathrm{a}$ & $196 \mathrm{a}$ & $149 \mathrm{~b}$ & $0.016(0.684)$ \\
\hline \multicolumn{5}{|c|}{ Average weight of the berry (grams) } \\
\hline Domoszló & $1.6 \mathrm{a}$ & $1.4 \mathrm{~b}$ & $1.4 \mathrm{~b}$ & 0.012 \\
\hline Helvécia & $1.8 \mathrm{a}$ & $1.4 \mathrm{~b}$ & $1.4 \mathrm{~b}$ & $0.004(0.319)$ \\
\hline Pölöske & $2.4 \mathrm{a}$ & $1.9 \mathrm{ab}$ & $1.8 \mathrm{~b}$ & 0.043 \\
\hline \multicolumn{5}{|l|}{ Average point of wine judging } \\
\hline Cserszegtomaj, 2008 & - & 17.5 & 18.4 & \\
\hline Domoszló, 2013 & 17.4 & 18.3 & 17.7 & \\
\hline Domoszló, 2014 & 17.2 & 17.4 & 17.6 & \\
\hline Domoszló, 2015 & 17.7 & 18.0 & 17.8 & \\
\hline \multicolumn{5}{|l|}{ Fertility $\left(\mathrm{kg} / \mathrm{m}^{2}\right)$} \\
\hline Domoszló & 1.04 & 1.00 & 0.89 & $0.820(0.388)$ \\
\hline Helvécia & 0.83 & 0.77 & 0.71 & $0.797(0.031)$ \\
\hline Cserszegtomaj & - & 1.51 & 0.92 & $0.107(0.468)$ \\
\hline \multicolumn{5}{|l|}{ Brix } \\
\hline Domoszló & 21.1 & 22.1 & 20.9 & $0.380(0.467)$ \\
\hline Helvécia & 21.2 & 20.9 & 22.2 & $0.180(0.947)$ \\
\hline Cserszegtomaj & - & 22.2 & 24.1 & $0.232(0.389)$ \\
\hline Refraction, brix \% (Pölöske) & 18.5 & 19.5 & 18.9 & $0.293(0.075)$ \\
\hline \multicolumn{5}{|c|}{ Titratable acidity of the must $(\mathrm{g} / \mathrm{L})$} \\
\hline Domoszló & 7.8 & 7.0 & 7.2 & $0.557(0.592)$ \\
\hline Helvécia & 7.0 & 6.5 & 6.3 & $0.793(0.528)$ \\
\hline Cserszegtomaj (2005-08) & - & 7.5 & 6.3 & $0.232(0.389)$ \\
\hline \multicolumn{5}{|c|}{ Titratable acidity of the wine $(\mathrm{g} / \mathrm{L})$} \\
\hline Domoszló & 6.8 & 6.6 & 6.2 & $0.156(0.957)$ \\
\hline Helvécia & 5.6 & 5.3 & 5.1 & $0.834(0.666)$ \\
\hline Cserszegtomaj & - & 5.9 & 6.0 & \\
\hline \multicolumn{5}{|c|}{ Tartaric acid content of the wine $(\mathrm{g} / \mathrm{L})$} \\
\hline Domoszló & 3.1 & 2.5 & 2.2 & $0.092(0.187)$ \\
\hline Helvécia & 2.4 & 2.3 & 2.4 & $0.940(0.840)$ \\
\hline \multicolumn{5}{|c|}{ Sugar-free extract of the wine $(\mathrm{g} / \mathrm{L})$} \\
\hline Domoszló & $26.9 \mathrm{a}$ & $28.6 \mathrm{~b}$ & $28.8 \mathrm{~b}$ & $0.044(0.181)$ \\
\hline Helvécia & 27.3 & 26.4 & 30.5 & $0.114(0.959)$ \\
\hline Cserszegtomaj (2016) & - & 23.1 & 28.0 & \\
\hline \multicolumn{5}{|l|}{ Degree of gray rot $(\%)$} \\
\hline Domoszló & 1.3 & 3.8 & 5.0 & \\
\hline Helvécia & 5.7 & 6.2 & 4.7 & \\
\hline
\end{tabular}

Homogeneous lowercase letters indicate that there is no significant difference.

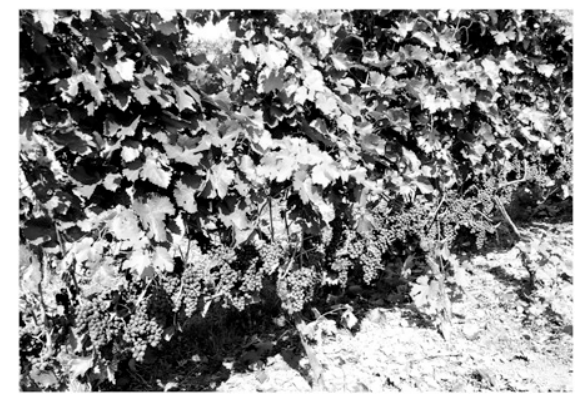

Fig. 2. 'Messiás'.

species (Table 1). Its wine is characterized by medium tartaric acid content $(2.2-2.4 \mathrm{~g} / \mathrm{L})$. The average content of tartaric acid contents of the examined years was low compared with other published values from Hungary (4-6 g/L) (Kállay et al., 2018). This could be because of the higher temperature during the vegetation period. The sugar-free extract and polyphenol content,

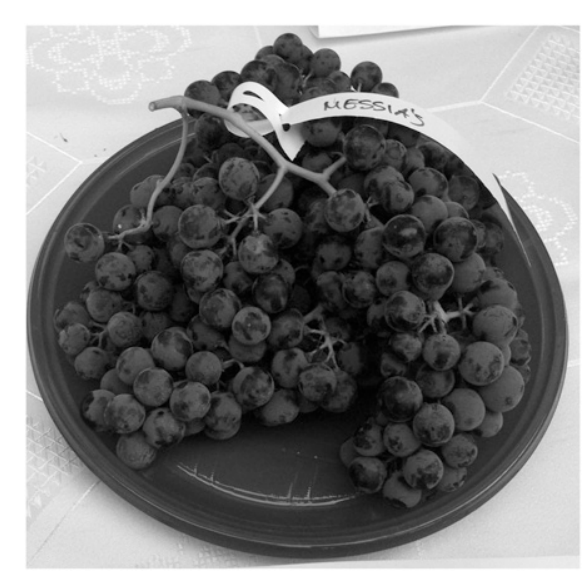

Fig. 3. 'Messiás' cluster.

the pigment quantity of the wine, and its deep color are remarkable.

The cultivar performed well in the sensory examination. It proved to be well suited to the experimented red wine cultivars that are widespread in Hungary. It consistently produces good-quality wines, and its quality is satisfactory regardless of vintage. Judges note its harmonious, full-bodied, often fruity but classic presentation. This wine typically has deep color. The wine produces mature tannins suitable for barrique aging.

Pathological characteristics. According to the NFCSO disease evaluation, 'Messiás' is moderately susceptible to downy mildew. It is less susceptible to cluster downy mildew than Merlot. Its susceptibility to powdery mildew is less than that of Kékfrankos and similar to Merlot. It is less susceptible to gray rot, compared with the red wine cultivars widespread in Hungary. During the study, gray rot infection of the berries occurred in 2016.

Cultivation properties. Budburst in 'Messiás' is medium-early, a few days before budburst in 'Kékfrankos'. Its flowering precedes that of 'Kékfrankos' and 'Merlot'. Early flowering and berry set are typical. Its budbreak starts several days before 'Kékfrankos' and 'Merlot'. The veraison begins in late July or the beginning of August. In most years, it can be harvested by $15 \mathrm{Sept}$. It is not prone to bunch rot, and thus the desired technological maturity can be achieved by choosing the harvest time carefully. Its growth is moderately intensive, and canopy management during the growing season is average. A yield of 8 to $10 \mathrm{t} /$ ha can be achieved with 8 to $10 \mathrm{bud} / \mathrm{m}^{2}$ bud load. It produces grapes on short spur, but higher yields are possible by using longer spurs. According to our experience, it is slightly sensitive to drought. It is primarily recommended in sites traditionally suitable for red cultivar production.

The cultivar has already been granted state recognition by the Hungarian National Food Chain Safety Office and has been registered in the National List of Cultivars.

\section{Availability of the Cultivar}

The Messiás grape cultivar is owned by the University of Pannonia Georgikon Faculty. Propagating materials are available at the Georgikon Educational Farm Nonprofit Ltd. The basic vineyard is under construction.

\section{Literature Cited}

Balga, I. 2014. Technológiai műveletek hatásai az Egri Bikavér élettanilag aktív vegyületeinek összetételére és érzékszervi tulajdonságaira. SZIE, PhD Diss.

Kálly, M., K. András, N.S. Katalin, and S.-L. Annamária. 2018. Első adatok a Purcsin szőlőfajta borának kémiai összetételéről. Borászati füzetek. XXVIII(6):28-31. 